\title{
Characterization of dissolved organic matter from temperate wetlands: field dynamics and photoreactivity changes driven by natural inputs and diagenesis along the hydroperiod
} \author{
Patricia E. García*, Carolina F. Mansilla Ferro and María C. Diéguez \\ Grupo de Ecología de Sistemas Acuáticos a escala de Paisaje (GESAP) INIBIOMA, \\ Universidad Nacional del Comahue, CONICET, Quintral 1250, San Carlos de Bariloche (8400), \\ Argentina. \\ *Corresponding author: garcia.patriciaelizabeth@gmail.com
}

\section{Abstract}

Wetlands store large amounts of $\mathrm{C}$ in biomass, sediments and water. A major $\mathrm{C}$ fraction is in the dissolved organic matter (DOM) pool and has multiple regulatory functions in the ecosystem. Patagonian wetlands undergo profound changes in their water cycle due to warming and reduced precipitation, causing shorter hydroperiods and reduced landscape connectivity and overall affecting their $\mathrm{C}$ budgets. In this study we characterized the DOM pool of a temporary wetland of North Patagonia during a hydroperiod, using optical DOM proxies obtained by absorption and fluorescence spectroscopy. DOM components were modeled through EEMPARAFAC. DOC varied between $\sim 4$ and $\sim 9 \mathrm{mg} \mathrm{L}^{-1}$, displaying aromatic signals and terrestrial/sediment fingerprints. The humic components $\mathrm{C} 1$ (microbial and/or vegetation derived) and C2 (soil/sediment derived) prevailed in the DOM pool, whereas the non-humic component C3 (derived from aquatic production) showed lower contribution. Along the hydroperiod DOM optical proxies allowed identifying allochthonous inputs, degradation and an increasing contribution of the internal production to the DOM pool. Photodegradation experiments showed that exposure to $\mathrm{PAR}+\mathrm{UVR}$ produced slight changes in the DOC concentration and a reduction in DOM molecular weight/size. The contribution of humic vs. non-humic components influenced DOM photoreactivity. The prevalence of humic components determined high DOM photorecalcitrance.

\section{Additional keywords:}

Patagonia, temperate wetlands, hydroperiod, dissolved organic carbon, degradation, photoreactivity 


\section{Introduction}

Wetlands occur in different climates and biomes, covering around 9\% of the world's land surface, and are considered among the most threatened ecosystems by climate changes, land use, water regulation and pollution (Brinson and Malvárez 2002; Keller 2011; van Asselen et al. 2013; Were et al. 2019; Xu et al. 2019).

These systems experience profound seasonal variations in water level, which can involve a succession of wet and dry periods, and also undergo high inter-annual fluctuations that imply extended periods of drought or flooding. Natural climate oscillations and human-induced changes impacting on the global water cycle have profound consequences for wetlands. Temperature, evaporation, humidity, and the seasonality and amount of precipitation drive the water cycle, thereby affecting most wetland processes (van Asselen et al. 2013; Häder and Barnes 2019).

Globally, wetlands are estimated to store $\sim 35 \%$ of terrestrial carbon $(\mathrm{C})$ and therefore play an important part in the global $\mathrm{C}$ cycle, although the pathways of $\mathrm{C}$ flux in these systems is still poorly understood. These ecosystems may affect the atmospheric C cycle through dynamic sequestration-emission processes (Denman et al. 2007). Wetlands can act as sinks for $\mathrm{C}$ from the terrestrial environment, can sequester $\mathrm{CO}_{2}$ from the atmosphere through photosynthesis of macrophytes and phytoplankton, and also transfer $\mathrm{C}$ to connected ecosystems. A large fraction of the total $\mathrm{C}$ present in wetlands is in the pool of dissolved organic matter (DOM) which includes a variety of compounds derived from the aquatic production (sediment and plant leachates, metabolites from aquatic organisms, etc.) as well as from soil and vegetation of the catchment. Macrophytes constitute a major source of particulate organic matter (POM) and DOM to the water and sediments of wetlands (Wetzel and Søndergaard 1998; Wetzel 2001; Yuan et al. 2020). DOM derived from aquatic production is composed of substances of comparatively lower aromaticity and molecular weight than terrigenous DOM (Cory and McKnight 2005; Stedmon and Markager 2005; Kritzberg et al. 2006; Murphy et al. 2008; Huguet et al. 2009). The concentration, composition and molecular structure of aquatic DOM is variable at spatial and temporal scales, and is ultimately determined by its interaction with environmental factors (climate variables, $\mathrm{pH}$, conductivity, sunlight exposure), other molecules and organisms (Fellman et al. 2009; Chen and Jaffé 2014; Hansen et al. 2016). In aquatic systems the DOM pool, and particularly its light-absorptive fraction (CDOM), determines the underwater light and 
65 thermal scenarios, and thus, exerts a chief control on their heterotrophic and autotrophic

66 production (Häder et al. 2011).

Temperate wetlands of the southern hemisphere have been comparatively less studied than tropical and subtropical wetlands with regard to their role in the global C cycle. In Andean Patagonia (Southern South America) temporary wetlands usually develop during autumn and last until early summer, experiencing freezing conditions at the beginning of the hydroperiod and warming up from late spring. Due to their geographical location and shallowness, their water columns are highly exposed to elevated ultraviolet (UV) radiation levels (Villafañe et al. 2001; Perotti et al. 2005; Díaz et al. 2006; Pérez et al. 2010). Challenging radiation levels enhance photochemical weathering affecting the $\mathrm{C}$ pool of aquatic systems, with profound effects on abiotic and biotic compartments (Zagarese et al. 2001; 2017; Pérez et al. 2003; Bastidas et al. 2009, 2010; Gerea et al. 2016).

In this investigation we focus on DOM dynamics in a cold temperate ephemeral wetland of Northwestern Patagonia over the course of a hydroperiod, aiming to characterize the natural DOM pool in terms of concentration and quality. We applied optical analysis of the light-absorbing properties of the chromophoric and fluorescent DOM fractions (CDOM and FDOM, respectively) in order to characterize the DOM quality in terms of potential sources, molecular features and diagenetic state. Additionally, we evaluated through laboratory assays the photoreactivity of natural DOM pools collected at different moments of the hydroperiod by exposing natural DOM to photosynthetically active radiation and ultraviolet radiation (PAR+UVR). We hypothesize that changes in DOM optical properties and photoreactivity along the hydroperiod reflect DOM inputs from different sources and degradation processes.

\section{Methods}

\section{Study area and field sampling}

93 The study was carried out in Fantasma Pond (FP; 41 $07^{\prime} \mathrm{S}, 71^{\circ} 27^{\prime} \mathrm{W} ; 798 \mathrm{~m}$ a.s.1.), a 94 shallow ( 2 m), temporary piedmont wetland of Andean Patagonia (Nahuel Huapi 95 National Park, Argentina). The climate of the area is cold temperate and markedly 96 seasonal with $\sim 60 \%$ of the precipitation concentrated from May to September 
97 (hereinafter the wet season). The wet season is characterized by cold temperatures and a short photoperiod, while the dry season (spring-summer) has much lower rainfall levels, warmer temperatures and a long photoperiod with enhanced ultraviolet radiation (UVR) levels, particularly in spring (Paruelo et al. 1998; Villafañe et al. 2001). In order to evaluate changes in the concentration and quality of the DOM pool of FP, water samples were collected monthly throughout the entire hydroperiod, from June to December. At each sampling occasion water level was recorded at the sampling point. Water temperature, $\mathrm{pH}$ and conductivity were measured using multiparameter probes. In November, the vertical profile of downward irradiance $(380-750 \mathrm{~nm}$, every $1 \mathrm{~nm})$ was measured at noon with a radiometer (USB2000, Ocean Optics).

Sampling was conducted at a central point of the wetland using a Kemmerer bottle (4.7 L). Water samples were poured into acid-cleaned polycarbonate carboys which were immediately transported to the laboratory thermally insulated and in darkness. In the laboratory the samples were filtered through $0.22 \mu \mathrm{m}$ polyvinylidene difluoride membranes (PVDF, Millipore) and stored in sealed dark flasks at $5^{\circ} \mathrm{C}$ for DOM characterization and photodegradation assays.

Precipitation and air temperature data for the studied period were retrieved from the meteorological station EMMA (INIBIOMA-CONICET) (Fig. S1).

\section{DOM photodegradation experiments}

Laboratory incubations were conducted to analyze the natural DOM photoreactivity of water samples collected in FP in six consecutive months of the hydroperiod. The experimental design targeted the effect of exposure to photosynthetically active radiation and $\mathrm{UV}$ radiation (PAR+UVR) on the concentration and quality of natural DOM. The experiments consisted in natural DOM incubation under two treatments (each with 3 replicates): exposed to PAR+UVR or in darkness (control). Filter-sterilized DOM samples were placed in capped quartz test tubes $(28 \mathrm{~mL})$ and the control tubes were wrapped with aluminum foil to prevent exposure to light. The replicates were set to rotate in a custom-made wheel at 1 RPM in an environmental test chamber (Sanyo, MLR5) for 5 days at $20^{\circ} \mathrm{C}$, with a photoperiod of $12 \mathrm{~h}$ PAR+UVR: $12 \mathrm{~h}$ darkness. Irradiation was provided through an array of 2 PAR lamps (Sanyo $40 \mathrm{~W}$ PAR $=69.1$ $\mu \mathrm{Em}^{-2} \mathrm{~s}^{-1}$ ), 2 UV-B lamps (Q-panel 320, UVB $=4.1 \mathrm{~kJ} \mathrm{~m}^{-2}$ ) and $3 \mathrm{UV}-\mathrm{A}$ lamps (Qpanel $340 \mathrm{UVA}=44 \mathrm{~kJ} \mathrm{~m}^{-2}$ ) (Fig. S2a). 


\section{Laboratory analysis}

133 DOM characterization in terms of concentration and quality was performed on the

134 filtered water samples collected throughout the hydroperiod and before and after 135 exposure to the different treatments (PAR+UVR and darkness) of the photodegradation 136 experiment.

137 The concentration of dissolved organic carbon (DOC) was measured in filtered water 138 samples as non-purgeable organic carbon using a Shimadzu TOC-L high temperature 139 analyzer with a high sensitivity catalyst (detection limit of $4 \mu \mathrm{g} \mathrm{L} \mathrm{L}^{-1}$ ).

140 Optical analyses were conducted to characterize the chromophoric and fluorescent 141 DOM fractions (CDOM and FDOM, respectively). The absorbance spectra of filter142 sterilized water samples were obtained at $1 \mathrm{~nm}$ intervals from 200 to $800 \mathrm{~nm}$ in a UV143 Visible spectrophotometer (Hewlett Packard 8450), using a quartz cuvette $(1 \mathrm{~cm}$ path 144 length). ASTM1 grade water (Milli-Q) was used as a blank. For analysis of the FDOM 145 fraction, the filtered, sterilized water samples were scanned in a Perkin-Elmer 55B 146 spectrofluorometer equipped with a 150-W Xenon arc lamp and a Peltier temperature 147 controller, using a $1 \mathrm{~cm}$ quartz fluorescence cell. Excitation-emission matrices (EEMs) 148 were collected at specific excitation (240-450 $\mathrm{nm}$ at $5 \mathrm{~nm}$ intervals) and emission (300$149600 \mathrm{~nm}$ at $0.5 \mathrm{~nm}$ intervals) wavelengths. The spectrofluorometer was set up with 10 $150 \mathrm{~nm}$ excitation and emission slits and a scan speed of $1500 \mathrm{~nm} \mathrm{~min}^{-1}$. As detailed above, ASTM1 grade water was used as a blank.

\section{Data analysis}

The averaged UV-visible absorbance between wavelengths 700 to $800 \mathrm{~nm}$ was subtracted from the absorbance spectra to correct for offsets due to several instrument

156 baseline effects, following Helms et al. (2008). The absorbance data were converted to 157 absorption coefficients as follows:

$\mathrm{a}_{\lambda}=$ Naperian coefficient $\left(\mathrm{m}^{-1}\right)=2.303 \mathrm{~A}_{\lambda} / 1$

$159 \mathrm{~A}=$ absorbance value

$1601=$ quartz cuvette path length $(\mathrm{m})=0.1 \mathrm{~m}$

161 The absorption coefficient at $350 \mathrm{~nm}\left(\mathrm{a}_{350}\right)$ was associated with terrigenous DOM 162 and/or with the concentration of lignin phenols (Hernes and Benner 2003; Spencer et al. 
163 2008). The specific absorption coefficient at $350 \mathrm{~nm}\left(\mathrm{a}_{350}: \mathrm{DOC}\right)$ was calculated and

164 used as a surrogate for DOM aromatic content (Weishaar et al. 2003; Hansen et al.

165 2016). The spectral slopes for the intervals $275-295 \mathrm{~nm}\left(\mathrm{~S}_{275-295}\right)$ and $350-400 \mathrm{~nm}\left(\mathrm{~S}_{350-}\right.$

166400 ) were calculated by fitting the log-transformed spectral data to a linear regression

167 (Helms et al. 2008). These slopes and the slope ratio $S_{R}\left(S_{R}=S_{275-295}: S_{350-400}\right)$ are

168 inversely related to DOM molecular size and aromaticity and are customarily used as

169 proxies for DOM degradation (Helms et al. 2008; Spencer et al. 2010; Fichot and

170 Benner 2012). The $S_{275-295}$ and $S_{350-400}$ and the $S_{R}$ generally increase on irradiation

171 (Helms et al. 2008; Hansen et al. 2016). The Climate Forcing Optical Index (CFOI) was

172 calculated as $\mathrm{a}_{320}$ :DOC divided by the spectral slope $\mathrm{S}_{275-295}$, and was applied as a proxy

173 of sunlight/photochemical weathering and terrestrial DOM inputs (Williamson et al.

174 2014).

175 Two fluorescent DOM compositional indicators were calculated from the fluorescence

176 scans of the samples. The humification index HIX, an indicator of humic content or

177 extent of humification, was calculated from the ratio of two integrated regions of an

178 emission scan $\left(\operatorname{Em}_{435-480}: \mathrm{Em}_{300-345}\right)$ at $\mathrm{Ex}_{254}$ (Zsolnay et al. 1999; Ohno 2002). High

179 HIX values indicate a high degree of humification (Hansen et al. 2016). The biological

180 index (BIX), a proxy for autotrophic production, was calculated as the ratio of the

181 emission intensities 380 and $430 \mathrm{~nm}\left(\mathrm{Em}_{380}\right.$ and $\left.\mathrm{Em}_{430}\right)$ at $\mathrm{Ex}_{310}$, following Huguet et al

182 (2009). BIX values >1 correspond to recently-produced DOM of autochthonous origin

183 (Hansen et al. 2016).

184 A total of 60 EEMs were processed using the software FL-WinLab ${ }^{\circledR}$ (Perkin-Elmer).

185 The absorbance spectra $(200-800 \mathrm{~nm})$ were used to develop a matrix of correction

186 factors for each EEM using the Matlab FDOMcorr toolbox, accounting for inner filter

187 effects, blank subtraction and normalization to the area under the water Raman peak of

188 the blank at $350 \mathrm{~nm}$. The resulting data were expressed in Raman units according to

189 Murphy et al. (2010).

190 Parallel Factor Analysis (PARAFAC) was applied to deconvolve DOM fluorescence

191 signals into specific components using the drEEM toolbox for MATLAB (MATLAB

192 R2015a) (Murphy et al. 2013).

193 A principal component analysis (PCA) was used to analyze the variation in the DOM

194 pool during the hydroperiod taking into account the water depth, the DOC

195 concentration, CDOM parameters $\left(\mathrm{a}_{350}\right.$ :DOC, $\left.\mathrm{S}_{275-295}, \mathrm{~S}_{350-400}, \mathrm{~S}_{\mathrm{R}}\right)$ and FDOM variables 
196 (HIX, BIX and the PARAFAC components). The analysis was performed using the

197 FactoMiner package in the R environment.

198 A linear model was fitted to the relationship between the absorption coefficient $\mathrm{a}_{350}$ and

199 DOC concentration. The results of the photodegradation assays were analyzed through

200 two-way ANOVA, using as factors the radiation treatments (PAR+UVR and Dark) and

201 the hydroperiod month (6 levels), using the free software R (package rstatix).

\section{Results and discussion}

\section{Dynamics of the dissolved organic matter pool during the hydroperiod}

205 The hydroperiod studied in FP lasted from June to December and reflected the 206 precipitation and temperature patterns, reaching its maximum volume in early spring 207 with the snowmelt water input, and then contracting until it completely dried up in early 208 summer (Fig. S1; Table 1). Similar hydroperiod patterns have been observed in 209 temporary wetlands adjacent to FP, which are typical of piedmont systems of the 210 Andean Patagonian region, showing slight differences due to local fluctuations in 211 precipitation volume (Cuassolo et al. 2012, 2015, 2020; Jara 2019).

212 The vegetation present in FP was characterized by a profuse ring of Carex 213 aemathorrhyncha covering $\sim 60 \%$ of the pond and a mixed cover of Eleocharis 214 pachycarpa and Potentilla anserina ( 10\% and $\sim 30 \%$, respectively) in the central 215 sector.

216 The water level at the sampling point varied from $\sim 0.6 \mathrm{~m}$ to $\sim 1.3 \mathrm{~m}$, showing higher 217 depths in August and September (Fig. S1; Table S1). Conductivity ranged from $75 \mu \mathrm{S}$ 218 and $106.3 \mu \mathrm{S}$, with higher values in September and October coinciding with higher 219 depths and water inputs due to increased runoff. The $\mathrm{pH}$ varied slightly around 220 neutrality showing a mean value of $7.4( \pm 0.4)$ and similarly lower values at the 221 beginning and at the end of the hydroperiod ( 6.5).

222 The DOC concentration ranged between $\sim 4$ and $\sim 9 \mathrm{mg} \mathrm{L}^{-1}$, with higher values at the 223 beginning and at the end of the hydroperiod, and lower values coinciding with the 224 higher depths recorded (Fig. 1a; Table S1). These DOC levels are within the range of 225 previously-reported concentrations for this wetland (Pérez et al. 2010; Cuassolo et al. 226 2012, 2020). The CDOM analysis resulted in high values of the coefficient $\mathrm{a}_{350}$, 227 indicative of terrigenous DOM and/or dissolved lignin content, particularly in the 
samples from the beginning and the end of the hydroperiod (Fig. 1b; Table S1). These high values of $\mathrm{a}_{350}$ likely reflected the contribution of DOM from surrounding soils [soil organic matter (SOM)], hygrophilous plants and bottom sediments, as indicated also by the direct relationship found between DOC concentration and $\mathrm{a}_{350}\left(\mathrm{R}^{2}=0.98 ; \mathrm{p}=0.001\right)$. The $\mathrm{a}_{350}$ :DOC values indicated high aromaticity of the DOM pool and was sensitive to eventual external inputs, such as recorded in September following a heavy rainfall that increased the runoff (Table S1). In ephemeral wetlands such as FP it is difficult to establish what is allochthonous and autochthonous, since the system alternates between dry (terrestrial phase) and flooded periods. The major sources of POM and DOM are the soils, bottom sediments and hygrophilous plants that can tolerate drought or flooding. Within FP, C. aemathorrhyncha and E. pachycarpa tolerate the drought period and develop large stands during the flooded period. Whereas, $P$. anserina dominates during the dry phase and decays during the hydroperiod, contributing substantially to the pools of POM, DOM and nutrients. This species decomposes faster than native species leaching coloured, high molecular weight DOM (Cuassolo et al. 2012, 2020). Thus, inputs from the decomposition of Potentilla and bottom sediments are likely important DOM sources during the initial flooding, along with contributions from the terrestrial vegetation and soils surrounding the pond that are mobilized by the runoff. The bottom sediments are known to contain large amounts of organic matter (Chimner et al. 2011), and the leaching that occurs on inundation sends an initial pulse of DOC into the water column of wetlands. Accordingly, the initial DOM pool of FP showed optical signatures indicative of high humic content and prevalence of compounds of high molecular weight/size and aromaticity (Table S1), resembling terrigenous inputs (García et al. 2018).

The different optical analyses performed on the natural water samples revealed changes in DOM quality over the course of the hydroperiod. Analysis of the CDOM fraction, and particularly the increase found in the spectral slopes $S_{275-295}, S_{350-400}$ and the $S_{R}$, indicated a decrease in the molecular weight/size of the DOM pool during the hydroperiod (Fig. 1c,d; Table S1). These changes point to degradation, probably the combined effect of biological and photochemical processing in the water column (Osburn et al. 2011; Lee et al. 2018). Moreover, the CFOI index, tracked the allochthonous inputs (reflected in high CFOI values) from June to August and indicated the impact of photodegradation on the DOM pool from September towards the end of the hydroperiod (lower CFOI Values). Biodegradation may be considered slow during 
262 the initial part of the hydroperiod (June to early September) due to the prevailing low

263 temperatures $\left(<8^{\circ} \mathrm{C}\right)$ and even freezing conditions; however, during spring the system

264 starts warming up, which favors biological activity, contributing to explain the stronger

265 degradation signals observed towards the end of the hydroperiod.

266 In aquatic systems of Andean Patagonia, UV radiation is a limiting factor for aquatic

267 biota and a key driver of biochemical processes in the water column, constituting a

268 governing factor of DOM transformation (Pérez et al. 2003; Marinone et al. 2006;

269 Zagarese et al. 1998, 2017). The region experiences high exposure to solar radiation in

270 spring and summer and high UV levels year-round due to its lati/altitudinal location

271 (Villafañe et al. 2001; Díaz et al. 2006). Moreover, from spring to autumn the longer

272 photoperiod with high UV levels enhances photochemical processes in the water

273 column (Queimaliños et al. 2019). In shallow wetlands a major fraction of the UV

274 radiation is absorbed in the first $10-20 \mathrm{~cm}$ (Fig. S2a), however, the water column is

275 mixed by the action of strong winds, which enhances photochemical weathering

276 (Zagarese et al. 1998, 2017). In spring, the pond displays a lower DOC concentration

277 due to the increase in water input as a consequence of snowmelt, promoting diluted

278 conditions and enhancing light penetration in the water column; such a pattern has been

279 observed in shallow lakes of the area (Soto Cárdenas et al. 2017).

280 The analysis of the FDOM fraction also supported the observed changes in DOM

281 quality reported above. First, the outcome of the PARAFAC modelling showed that the

282 FDOM pool of FP is composed of two humic-like components (C1 and C2) and one

283 non-humic component (C3) (Table S2). The fluorescent components C1 and C2 showed

284 two excitation maxima at a single emission spectrum, as a combination of two

285 fluorescent peaks [C1 (A + M peaks) and C2 (A + C peaks)]. Whereas, C3 was

286 characterized by a single peak, corresponding to peak $\mathrm{T}$. The fluorescent peaks A and $\mathrm{M}$

287 included in $\mathrm{C} 1$ likely correspond to humic substances originating from microbial

288 activity, while peaks $\mathrm{A}+\mathrm{C}$ included in $\mathrm{C} 2$ have been attributed to terrestrially-derived

289 humic compounds. Component C3, characterized by the T peak, has been associated

290 with non-humic compounds of autochthonous origin (aquatic production) (Table S2).

291 Throughout the hydroperiod the humic components $\mathrm{C} 1$ and $\mathrm{C} 2$ prevailed in the DOM

292 pool, whereas C3 showed a smaller contribution (Fig. 2b).

293 The intensities of the three fluorescent components followed the DOC concentration

294 pattern (Fig. 1a; Fig. 2a). However, the DOC-normalized components displayed a

295 relatively stable and prevalent contribution of the humic components $\mathrm{C} 1$ and $\mathrm{C} 2$ and an 
296 increase in C3 during the hydroperiod (Fig. 2b). This pattern was supported by the high

297 HIX values highlighting the contribution of vegetation and soil/sediment DOM. In

298 addition, the increasing contribution of C3 and BIX mirrored the growing input of the

299 aquatic production over the course of the hydroperiod (Fig. 2b, c).

300 The PCA analysis performed to analyze variation in the DOM pool during the

301 hydroperiod, taking into account DOC concentration, CDOM parameters and FDOM

302 variables, resulted in two valid principal components (PC). PC1 and PC2 contributed to

303 explain $57.2 \%$ and $29.9 \%$, respectively, accounting to explain $87.11 \%$ of the total

304 variance (Table S3). PC1 correlated positively with the DOC concentration, $\mathrm{a}_{350}$ :DOC,

$305 \mathrm{C} 1, \mathrm{C} 2$, and HIX, and showed a negative correlation with water depth, $\mathrm{S}_{275-295}$ and $\mathrm{S}_{\mathrm{R}}$

306 (Fig. 3; Table S3). PC2 correlated positively with the degradation proxies $\mathrm{S}_{275-295}$ and

$307 \mathrm{~S}_{350-400}$ and with the proxies of autochthonous production, C3 and BIX. Along the PC1

308 axis two groups of samples were distinguished. On the right of the plot, samples from

309 June, July and December were grouped, based on their higher DOC, a 350 :DOC, high C1

310 and C2 intensities and HIX and corresponding with lower depths of the wetland. Based

311 on contrasting values of the contributing variables, samples from August, September

312 and October were clustered on the left of the plot (Fig. 3). PC2 separated the samples

313 from September, October and December with higher values of $\mathrm{S}_{350-400}$, C3 and BIX,

314 indicative of higher degradation and the contribution of autochthonous biological

315 activity (Fig. 3). Overall, the PCA allowed discriminating samples with high DOC

316 concentrations supported by differences in DOM quality. Samples from the beginning

317 of the hydroperiod, derived from vegetation and soil/sediment inputs, showed a strong

318 humic fingerprint. In contrast, those from the end of the hydroperiod reflected

319 autochthonous production. Regarding the vegetation inputs, it is difficult to discriminate

320 between the contributions of terrestrial and hygrophilous vegetation to the DOM pool of

321 the pond, since they are both sources of high molecular weight and aromatic DOM due

322 to their lignin and cellulose contents (Talbot and Treseder 2012; Hansen et al. 2016).

323 Collectively, these results indicate that over the course of the hydroperiod, the DOM

324 pool of FP showed pronounced concentration and quality changes. Although the

325 prevailing DOM sources appear to be terrestrial and hygrophilous vegetation and the

326 soils and bottom sediments, the contribution of aquatic production increases from early

327 spring towards the end of the hydroperiod. The aquatic contribution could be tracked

328 through the increase in the C3 and BIX, likely enhanced by the activity of aquatic 
329 vegetation, microbiota (plankton, sediment microbiota, epiphytic microbial

330 communities, etc.) and their metabolites. The changes observed in the concentration and

331 quality of the DOM pool along the hydroperiod suggested that inputs and degradation

332 might trigger DOM reactivity changes. This hypothesis was tested through

333 photodegradation experiments performed with DOM samples collected monthly during

334 the hydroperiod.

\section{Photodegradation experiments}

336 Photodegradation experiments were performed by exposing water samples to

337 PAR+UVR and dark treatments. Significant differences were detected in CDOM and

338 FDOM proxies between treatments and across samples from different months of the

339 hydroperiod (Table S4), suggesting that natural changes in DOM concentration and

340 quality influenced the magnitude of photodegradation.

341 The effect of irradiation on DOC concentration was rather idiosyncratic among the 342 water samples studied. Notably, samples from September and December showed a 343 significant reduction in DOC concentration on exposure to $\mathrm{PAR}+\mathrm{UV}$, whereas in the 344 other samples the trend was opposite or not significant (Fig. 4a).

345 In terms of changes in DOM quality, the PAR+UV treatment produced a significant loss 346 of absorbance in the water samples, reflected in lower values of the $\mathrm{a}_{350}$ :DOC, and a 347 significant increase in $\mathrm{S}_{275-295}$ and $\mathrm{S}_{\mathrm{R}}$, indicative of a reduction in DOM molecular 348 weight/size (Table S4; Fig.4 b, c). The intensity of the three fluorescent components 349 decreased significantly on irradiation; however, differences in the loss of fluorescence 350 were detected among the three components (Fig. $4 \mathrm{~d}$, f; Table S4). The humic 351 component $\mathrm{C} 1$ and the non-humic $\mathrm{C} 3$ showed higher loss of fluorescence intensity than 352 the humic component $\mathrm{C} 2$, which was comparatively more stable or photoresistant (Fig. 353 4d-f).

354 The negative slopes of the relationship between $\mathrm{a}_{350}$ and $\mathbf{S}_{275-295}$ computed for all the 355 incubations (Fig. 5a) indicated that exposure to radiation consistently reduced DOM 356 molecular weight/size, although the range of the slope values suggested differences in 357 the degree of transformation among samples, even in those with similar $\mathrm{a}_{350}$ values (Fig. 358 5a). The relationship $\mathrm{a}_{350}$ vs. $\mathrm{S}_{275-295}$ allowed the detection of differences in photo359 degradation of the DOM pools from different moments of the hydroperiod, regardless of 360 DOC concentration. The magnitude of photodegradation reflects changes in DOM, 361 likely related to its composition and/or diagenetic state. This idea is also supported by 
362 the relationship found between the intensity of the three fluorescent components and

$363 \mathrm{~S}_{275-295}$, which showed differences in photoreactivity. Steeper slopes were found in the

364 case of $\mathrm{C} 1$ and $\mathrm{C} 3$, while a smoother pattern was observed in the case of $\mathrm{C} 2$, indicating

365 its photo-resistant condition (Fig. 5 b-d). The photoreactivity of the components can

366 therefore be characterized as $\mathrm{C} 1>\mathrm{C} 3>\mathrm{C} 2$. The humic component $\mathrm{C} 1$ includes

367 compounds probably derived from microbial sources, and was more

368 photolabile/photoreactive than the humic component $\mathrm{C} 2$, which has a stronger

369 soil/sediment fingerprint. Furthermore, the stability displayed by C2 in the DOM pool

370 throughout the hydroperiod may be taken as an indication of its recalcitrance also to

371 biological degradation (Fig. 2b). Other investigations focusing on the photoreactivity of

372 DOM in running waters and shallow permanent lakes in the same catchment have also

373 reported high recalcitrance of the humic component C2 (or A+C peaks) (Soto Cárdenas

374 et al. 2017; García et al. 2018).

\section{Conclusions}

The DOC concentration and quality of the wetland varied markedly over the hydroperiod in response to inputs from terrestrial, hygrophilous vegetation and soil/sediment DOM.

381 Higher DOC concentrations were found at the beginning and at the end of the

382 hydroperiod, coinciding with the lower water levels, while lower DOC concentrations

383 were recorded at the end of winter and in early spring, following the rise in water level

384 due to snowmelt.

385 The DOM pool of the wetland was characterized by the prevalence of high molecular

386 weight, aromatic DOM with strong soil/sediment and vegetation (terrestrial and

387 hygrophilous) fingerprints.

388 The progression of degradation and a low but increasing contribution of internal 389 production to the DOM pool was detected over the hydroperiod.

390 In laboratory experiments, DOM photochemical transformation involved only minor

391 changes in DOC concentration but significant changes in quality, as indicated by several 392 optical proxies of degradation and biological production.

393 Changes in the relative contribution of the humic vs. non-humic components, 394 specifically by the components $\mathrm{C} 1$ and $\mathrm{C} 3$, determined the reactivity and photo395 degradability $(\mathrm{C} 1>\mathrm{C} 3>\mathrm{C} 2)$ of the DOM pools at different moments of the hydroperiod. 
396 Our results suggest that the cold temperate wetlands of Andean Patagonia can process a

397 moderate amount of the $\mathrm{C}$ pool they receive/produce due to the combined effect of their

398 DOM quality (highly recalcitrant) and the low temperature that prevails during most of

399 the hydroperiod, which dampens biodegradation. Despite the importance of

400 photodegradation processes, the high resistant DOM pool prevents photo-mineralization

401 during the short hydroperiod, leading to accumulation of recalcitrant material in the

402 sediments that may be subjected to weathering and microbial processing during the dry

403 phase.

\section{Declaration of Funding}

This work was supported by the Agencia Nacional de Promoción Científica y 408 Tecnológica (PICT 2019-0026 to PEG; PICT 2016-0499 to MCD). P. E. García and M.

409 C. Diéguez are CONICET researchers and C. F. Mansilla Ferro is a CONICET fellow.

\section{Conflicts of interest}

411 The authors declare no conflicts of interest.

\section{Acknowledgments}

We thank the town council of San Carlos de Bariloche for granting permission to collect samples in Fantasma pond, and to Mrs Audrey Shaw for language revision of the manuscript.

\section{References}

Bastidas Navarro, M., and Modenutti, B. (2010). UVR induce optical changes and phosphorous release of lake water and macrophyte leachates in shallow Andean lakes. Journal of Limnology, 69, 112-119. water and macrophyte leachates in shallow Andean-Patagonian lakes: bacterial Response to Changes in Optical Features. Photochemistry and Photobiology, 85, 332-340.

Brinson, M., and Malvárez, A. (2002). Temperate freshwater wetlands: Types, status, and threats. Environmental Conservation, 29, 115-133.

Chen, M., and Jaffé, R. (2014). Photo- and bio-reactivity patterns of dissolved organic matter from biomass and soil leachates and surface waters in a subtropical wetland. Water Research, 61, 181-190. 
430

431

432

433

434

435

436

437

438

439

440

441

442

443

444

445

446

447

448

449

450

451

452

453

454

455

456

457

458

459

460

461

462

463

464

465

466

467

468

469

470

471

472

473

474

475

476

477

478

Chimner, R. A., Bonvissuto, G., Cremona, Cremona, V., and López, C. (2011). Ecohydrological conditions of wetlands along a precipitation gradient in Patagonia, Argentina. Ecologia Austral, 21, 329-337.

Cory, R. M., and McKnight, D. M. (2005). Fluorescence spectroscopy reveals ubiquitous presence of oxidized and reduced quinones in dissolved organic matter. Environmental Science and Technology, 39, 8142-8149.

Cuassolo, F., Balseiro, E., and Modenutti, B. (2012). Alien vs. native plants in a Patagonian wetland: elemental ratios and ecosystem stoichiometric impacts. Biological Invasions, 14, 179-189.

Cuassolo, F., Bastidas, N. M., Balseiro, E. and Modenutti, B. (2015). Effect of light on particulate and dissolved organic matter production of native and exotic macrophyte species in Patagonia. Hydrobiologia, 766, 29-42.

Cuassolo, F., Díaz, V.V., and Modenutti, B. (2020). Litter decomposition of the invasive Potentilla anserina in an invaded and non-invaded freshwater environment of North Patagonia. Biological Invasions, 22, 1055-1065.

Denman, K.L., Brasseur, G., Chidthaisong, A., Ciais, P., Cox, P.M., Dickinson, R.E., Hauglustaine, D., Heinze, C., Holland, E., Jacob, D., Lohmann, U., Ramachandran, S., da Silva Dias, P.L., Wofsy S.C. and Zhang, X. (2007): Couplings Between Changes in the Climate System and Biogeochemistry. In: Climate Change 2007: The Physical Science Basis. Contribution of Working Group I to the Fourth Assessment Report of the Intergovernmental Panel on Climate Change. Solomon, S., Qin, D., Manning, M., Chen, Z., Marquis, M., Averyt, K.B., Tignor, M.and Miller,H.L. (eds.). Cambridge University Press, Cambridge, United Kingdom and New York, NY, USA.

Díaz, S., Camilión, C., Deferrari, G., Fuenzalida H., Armstrong R., Booth, C., Paladini, A., Cabrera, S., Casiccia, C., Lovengreeng, C., Pedroni, J., Rosales, A., Zagarese. H., and Vernet, M. (2006). Ozone and UV Radiation over Southern South America: Climatology and Anomalies. Photochemistry and Photobiology, 82, 834-843.

Fellman, J. B., Hood, E., D’Amore, D. V., Edwards, R. T, and White, D. (2009). Seasonal changes in the chemical quality and biodegradability of dissolved organic matter exported from soils to streams in coastal temperate rainforest watersheds. Biogeochemistry, 95, 277-293.

Fichot, C. G., and Benner, R. (2012). The spectral slope coefficient of chromophoric dissolved organic matter (S275-295) as a tracer of terrigenous dissolved organic carbon in river-influenced ocean margins. Limnology and Oceanography, 57, 14531466.

García, R. D., Diéguez, M. C., Gerea, M., García, P. E., and Reissig, M. (2018). Characterization and reactivity continuum of dissolved organic matter in forested headwater catchments of Andean Patagonia. Freshwater Biology, 63, 1049-1062.

Gerea, M., Pérez, G. L., Unrein, F., Soto Cárdenas, C., Morris, D., and Queimaliños, C. (2016). CDOM and the underwater light climate in two shallow North Patagonian lakes: evaluating the effects on nano and microphytoplankton community structure. Aquatic Science, 79, 231-248.

Häder, D.P., Helbling, E. W., Williamson, C. E., and Worrest, R. C. (2011). Effects of UV radiation on aquatic ecosystems and interactions with climate change. Photochemical and Photobiological Sciences, 10, 242-260.

Häder, D. P., and Barnes, P. W. (2019). Comparing the impacts of climate change on the responses and linkages between terrestrial and aquatic ecosystems. Science of the Total Environment, 682, 239-246. 
Hansen, A. M., Kraus, T. E, Pellerin, B. A, Fleck, J. A., Downing, B. D., and Bergamaschi, B. A. (2016). Optical properties of dissolved organic matter (DOM): Effects of biological and photolytic degradation. Limnology and Oceanography, 61, 1015-1032.

Helms, J. R., Stubbins, A., Ritchie, J. D., Minor, E. Z., Kieber, D. J, and Mopper, K. (2008). Absorption spectral slopes and slope ratios as indicators of molecular weight, source, and photobleaching of chromophoric dissolved organic matter. Limnology and Oceanography, 53, 955-969.

Hernes, J. P., and Benner, R. (2003). Photochemical and microbial degradation of dissolved lignin phenols: Implications for the fate of terrigenous dissolved organic matter in marine environments. JGR Oceans, 108,(C9).

Huguet, A., Vacher, L., Saubusse, S., Etcheber, H., Abril, G., Relexans, S., Ibalot, F., and Parlanti, E. (2009). New insights into the size distribution of fluorescent dissolved organic matter in estuarine waters. Organic Geochemistry, 41, 595-610.

Jara, F. G. (2019). The impact of phenology on the interaction between a predaceous aquatic insect and larval amphibians in seasonal ponds. Hydrobiologia, 835, 49-61.

Keller, J. K. (2011). Wetlands and the global carbon cycle: what might the simulated past tell us about the future? (2011). New Phytologist, 192, 789-792

Kritzberg, E. S., Langenheder, S., and Lindström, E. S. (2006). Influence of dissolved organic matter source on lake bacterioplankton structure and function - implications for seasonal dynamics of community composition. FEMS Microbiology Ecology, 56, 406-417.

Lee, M., Osburn, C. L., Shin, K., and Hur, J. (2018). New insight into the applicability of spectroscopic indices for dissolved organic matter (DOM) source discrimination in aquatic systems affected by biogeochemical processes. Water Research, 147, 164176.

Marinone, M. C., Menu Marque, S., Añón Suárez, D., Diéguez, M. C., Pérez, A. P., De Los Ríos, P., Soto, D. and Zagarese, H. E. (2006). UVR Radiation as a Potential Driving Force for Zooplankton Community Structure in Patagonian Lakes. Photochemistry and Photobiology, 82, 962-971.

Murphy, K. R., Stedmon, C. A., Waite, T. D., and Ruiz, G. (2008). Distinguishing between terrestrial and autochthonous organic matter sources in marine environments using fluorescence spectroscopy. Marine Chemistry, 108, 40-58.

Murphy, K. R., Butler, K. D., Spencer, R. G. M., Stedmon, C. A., Boehme, J. R., and Aiken, G.R. (2010). Measurement of dissolved organic matter fluorescence in aquatic environments: an interlaboratory comparison. Environmental Science and Technology, 44, 9405-9412.

Murphy, K. R., Stedmon, C. A., Graeber, D., and Bro, R. (2013) Fluorescence spectroscopy and multi-way techniques. PARAFAC. Analytical Methods, 5, 65576566.

Ohno, T. (2002). Fluorescence inner-filtering correction for determining the humification index of dissolved organic matter. Environmental Science and Technology, 36, 742-746

Osburn, C. L., Wigdahl, C. R., Fritz, S. C., and Saros, J. E. (2011). Dissolved organic matter composition and photoreactivity in prairie lakes of the U.S. Great Plains. Limnology and Oceanography, 56, 2371-2390.

Paruelo, J. M., Beltran, A., Jobbágy, E., Sala, O. E., Golluscio, R. A., 1998. The climate of Patagonia: general patterns and controls on biotic processes. Ecología Austral, 8, 85-101. 
Pérez, G. L, Torremorell, A., Bustingorry, J., Escaray, R., Pérez, P. A., Diéguez, M.C., and Zagarese, H. E. (2010). Optical characteristics of shallow lakes from the Pampa and Patagonia regions of Argentina. Limnologica, 40, 30-39.

Pérez, P. A, Díaz, M. M, Ferraro, M. A, Cusminsky, G.C, and Zagarese, H. E. (2003). Replicated mesocosm study on the role of natural ultraviolet radiation in high CDOM, shallow lakes. Photochemical and Photobiological Sciences, 2, 118-123.

Perotti, M. G, Diéguez, M. C, and Jara, F. G. (2005). State of the knowledge of north Patagonian wetlands (Argentina): major aspects and importance for regional biodiversity conservation. Revista chilena de historia natural, 78, 723-737.

Queimaliños, C., Reissig, M., Pérez, G. L., Cárdenas, C. S., Gerea, M., Garcia, P. E., García, R. D. and Diéguez, M. C. (2019). Linking landscape heterogeneity with lake dissolved organic matter properties assessed through absorbance and fluorescence spectroscopy: Spatial and seasonal patterns in temperate lakes of Southern Andes (Patagonia, Argentina). Science of the Total Environment, 686, 223-235.

Soto Cárdenas, C., Gerea, M., Garcia, P. E., Pérez, G. L., Diéguez, M. C., Rapacioli, R., Reissig, M., and Queimaliños, C. (2017). Interplay between climate and hydrogeomorphic features and their effect on the seasonal variation of dissolved organic matter in shallow temperate lakes of the Southern Andes (Patagonia, Argentina): a field study based on optical properties. Ecohydrology, 10, e1872.

Spencer, R. G. M., Aiken, G. R., Wickland, K. P., Striegl, R.G, and Hernes, P. J. (2008). Seasonal and spatial variability in dissolved organic matter quantity and composition from the Yukon River basin, Alaska. Global Biogeochemical Cycles, 22, GB4002.

Spencer, R. G. M., Hernes, P. J., Ruf, R., Baker, A., Dyda, R. Y., Stubbins, A., and Six, J. (2010). Temporal controls on dissolved organic matter and lignin biogeochemistry in a pristine tropical river, Democratic Republic of Congo. JGR Biogeosciences, 115, G03013.

Stedmon, C. A, and Markager, S. (2005). Tracing the production and degradation of autochthonous fractions of dissolved organic matter by fluorescence analysis. Limnology and Oceanography, 50, 1415-1426.

Talbot, J. M., and Treseder, K. (2012). Interactions among lignin, cellulose, and nitrogen drive litter chemistry-decay relationships. Ecology, 93, 345-354.

van Asselen, S., Verburg, P. H., Vermaat, J. E. and Janse, J. H. (2013). Drivers of wetland Conversion: a Global Meta-Analysis. PLoS ONE, 8, e81292.

Villafañe, V. E., Helbling, E. W., and Zagarese, H. E. (2001). Solar ultraviolet radiation and its impact on aquatic systems of Patagonia, South America. AMBIO, 30, 112117.

Weishaar, J. L., Aiken, G. R., Bergamaschi, B. A., Fram, M. S., Fujii, R., and Mopper, K. (2003). Evaluation of specific ultraviolet absorbance as an indicator of the chemical composition and reactivity of dissolved organic carbon. Environmental Science and Technology, 37, 4702-4708.

Were, D., Kansiime, F., Fetahi, T., Cooper, A. and Jjuuko, C. (2019). Carbon Sequestration by Wetlands: A Critical Review of Enhancement Measures for Climate Change Mitigation. Earth Systems and Environment, 3, 327-340.

Wetzel, R. G. (2001). Limnology. Lake and river ecosystems. San Diego: Academic Press.

Wetzel, R. G., and Søndergaard, M. (1998). Role of submerged macrophytes for the microbial community and dynamics of dissolved organic carbon in aquatic ecosystems. In: The structuring role of submerged macrophytes in lakes (pp. 133148). Springer, New York, NY. 
578 Williamson, C. E., Brentrup, J. A., Zhang, J., Renwick, W. H., Hargreaves, B. R.,

579 Knoll, L. B., Overholt, E. P. and Rose, K. C. (2014). Lakes as sensors in the

$580 \quad$ landscape: optical metrics as scalable sentinel responses to climate change.

$581 \quad$ Limnology and Oceanography, 59, 840-850.

Xu, T., Weng, B., Yan, D., Wang, K., Li, X., Bi, W., Li, M., Cheng, X., and Liu, Y. (2019) Wetlands of International Importance: Status, Threats, and Future Protection. International Journal of Environmental Research and Public Health, 16, 1818-1840.

Yuan, D., Zhao, Y., Guo, X., Zhai, L., Wang, X., Wang, J., Cui, Y., He, L., Yan, C., and Kou, Y. (2020). Impact of hydrophyte decomposition on the changes and characteristics of dissolved organic matter in lake water. Ecological Indicators, 116, 106482.

Zagarese, H. E., Tartarotti, B., Cravero, W., and Gonzalez, P. (1998). UV damage in shallow lakes: the implications of water mixing. Journal of Plankton Research, 20, 1423-1433.

Zagarese, H. E., Díaz, M. M., Pedrozo, F. L., and Tartarotti, B. (2001). Photodegradation of natural organic matter exposed to fluctuating levels of solar radiation. Photochemistry and Photobiology B: Biology, 61, 35-45.

Zagarese, H. E., Ferraro, M., Queimaliños, C., Diéguez, M. C., Añón Suárez, D., Llames, M. E. (2017) Patterns of dissolved organic matter across the Patagonian landscape: a broad scale survey of Chilean and Argentine lakes. Marine and Freshwater Research, 68, 1-11.

Zhu, W. Z., Zhang, H. H., Zhang, J., Yang, G. P., 2018. Seasonal variation in chromophoric dissolved organic matter and relationships among fluorescent components, absorption coefficients and dissolved organic carbon in the Bohai Sea, the Yellow Sea and the East China Sea. Journal of Marine Systems, 180, 9-23.

Zsolnay, A., Baigar, E., Jimenez, M., Steinweg, B., and Saccomandi, F. (1999). Differentiating with fluorescence spectroscopy the sources of dissolved organic matter in soils subjected to drying. Chemosphere, $\mathbf{3 8}, 45-50$. 


\section{Figure captions}

609 Figure 1. Monthly variation in different parameters of the dissolved organic matter 610 (DOM) pool during a hydroperiod of Fantasma pond (North Patagonia, Argentina): a) 611 Dissolved organic carbon (DOC) concentration; b) Absorption coefficients $\mathrm{a}_{254}$ and $\mathrm{a}_{350}$ 612 (applied as proxies for aromaticity); c) Spectral Slope $S_{275-295}$, and d) Slope ratio $\mathrm{S}_{\mathrm{R}}$ $613\left(\mathrm{~S}_{275-295}: \mathrm{S}_{350-400}\right)$ (applied as proxies for molecular weight and degradation).

614 Figure 2. Variation in FDOM parameters over a hydroperiod of Fantasma pond: a) 615 Intensity of the PARAFAC components C1, C2 and C3; b) DOC-normalized intensity 616 of the FDOM components C1, C2 and C3, and c) Humification index (HIX: black 617 dotted line) and Biological Index (BIX: red solid line).

618 Figure 3. Plot of the Principal Component Analysis (PCA) PC1 vs. PC2 performed to 619 study variation in the DOM pool of Fantasma Pond over a hydroperiod, including DOC 620 concentration and CDOM ( $\mathrm{a}_{254} ; \mathrm{a}_{350} ; \mathrm{SUVA} ; \mathrm{a}_{350}: D O C ; \mathrm{S}_{275-295} ; \mathrm{S}_{350-400}$ and $\left.\mathrm{S}_{\mathrm{R}}\right)$ and 621 FDOM proxies (fluorescent components $\mathrm{C} 1, \mathrm{C} 2$ and $\mathrm{C} 3$; and the humification and 622 biological indexes: HIX and BIX).

623 Figure 4. Changes in DOM properties in laboratory incubations under PAR+UVR and 624 DARK treatments performed to study the DOM photoreactivity of DOM samples 625 collected monthly during a hydroperiod in Fantasma Pond: a) DOC concentration; b) 626 Spectral slope $S_{275-295} ;$ c) Slope ratio $S_{R}\left(S_{275-295}: S_{350-400}\right)$; d) fluorescent component C1; 627 e) fluorescent component $\mathrm{C} 2$, f) fluorescent component $\mathrm{C} 3$.

628 Figure 5. Relationship between the absorption coefficient $\mathrm{a}_{350}$ (a), the fluorescent 629 components C1 (b), C2 (c) and C3 (d) and the spectral slope $\mathrm{S}_{275-295}$ in DOM samples 630 collected monthly from Fantasma Pond and incubated under PAR+UVR in the 631 laboratory. 


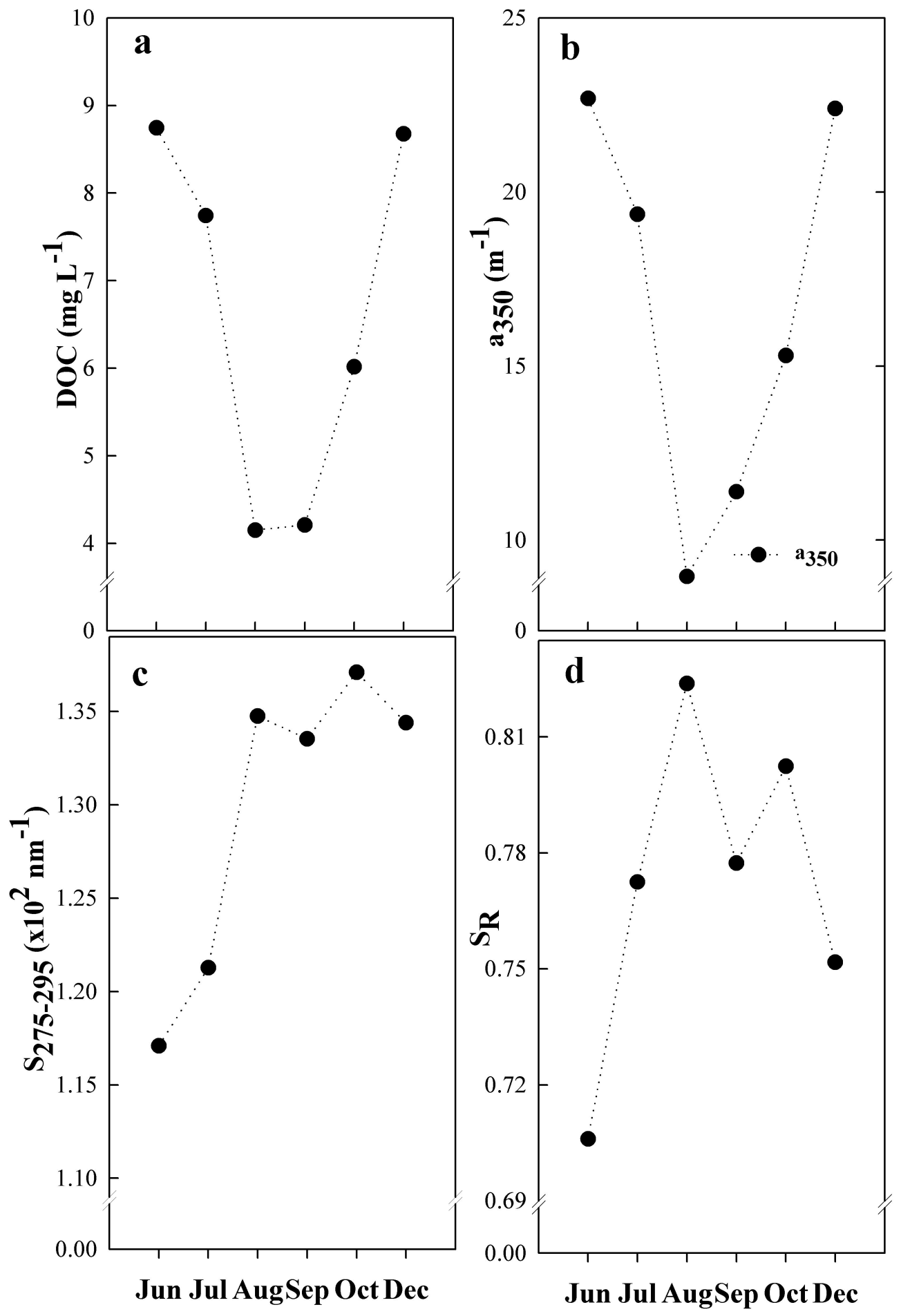




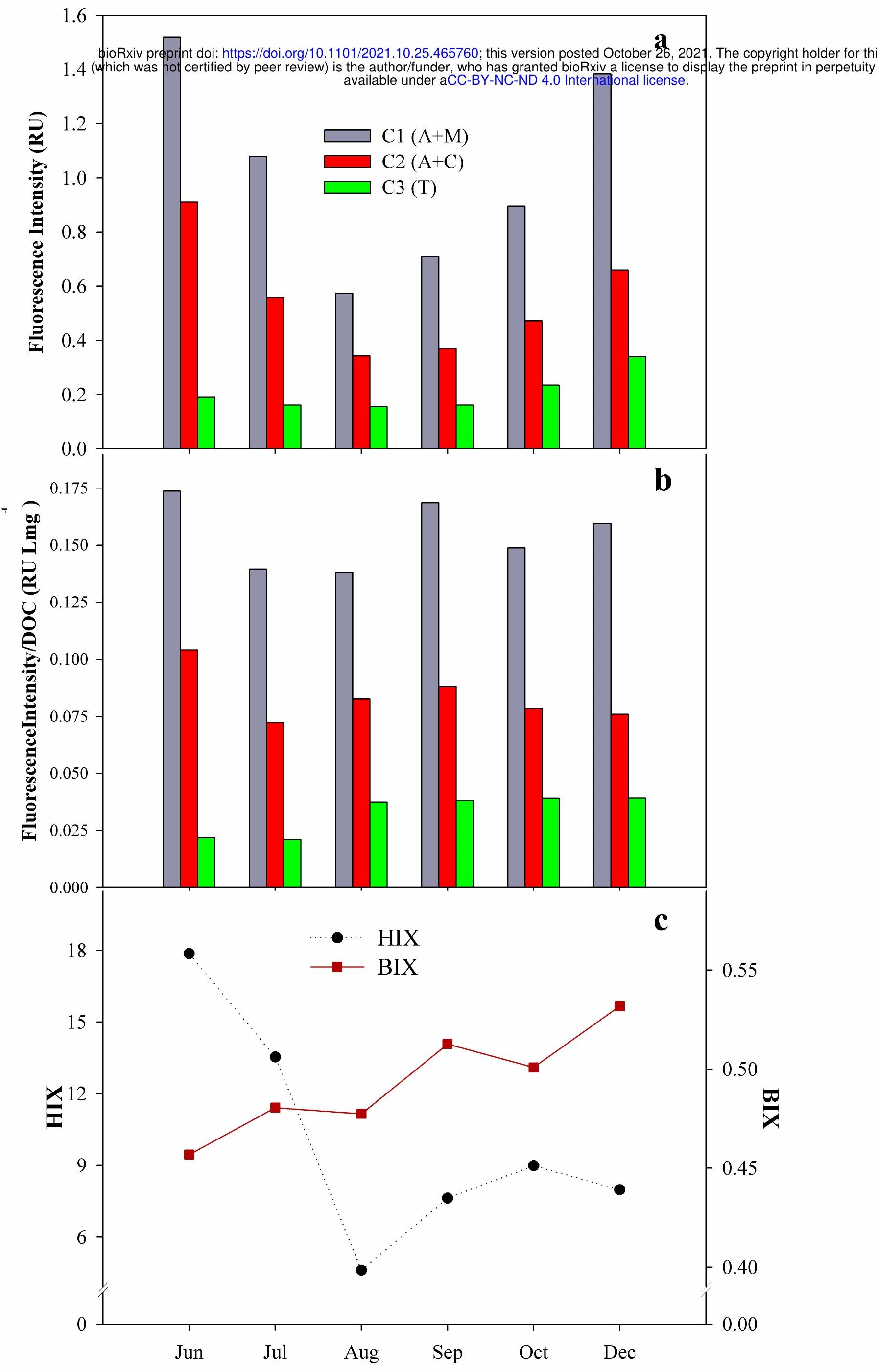




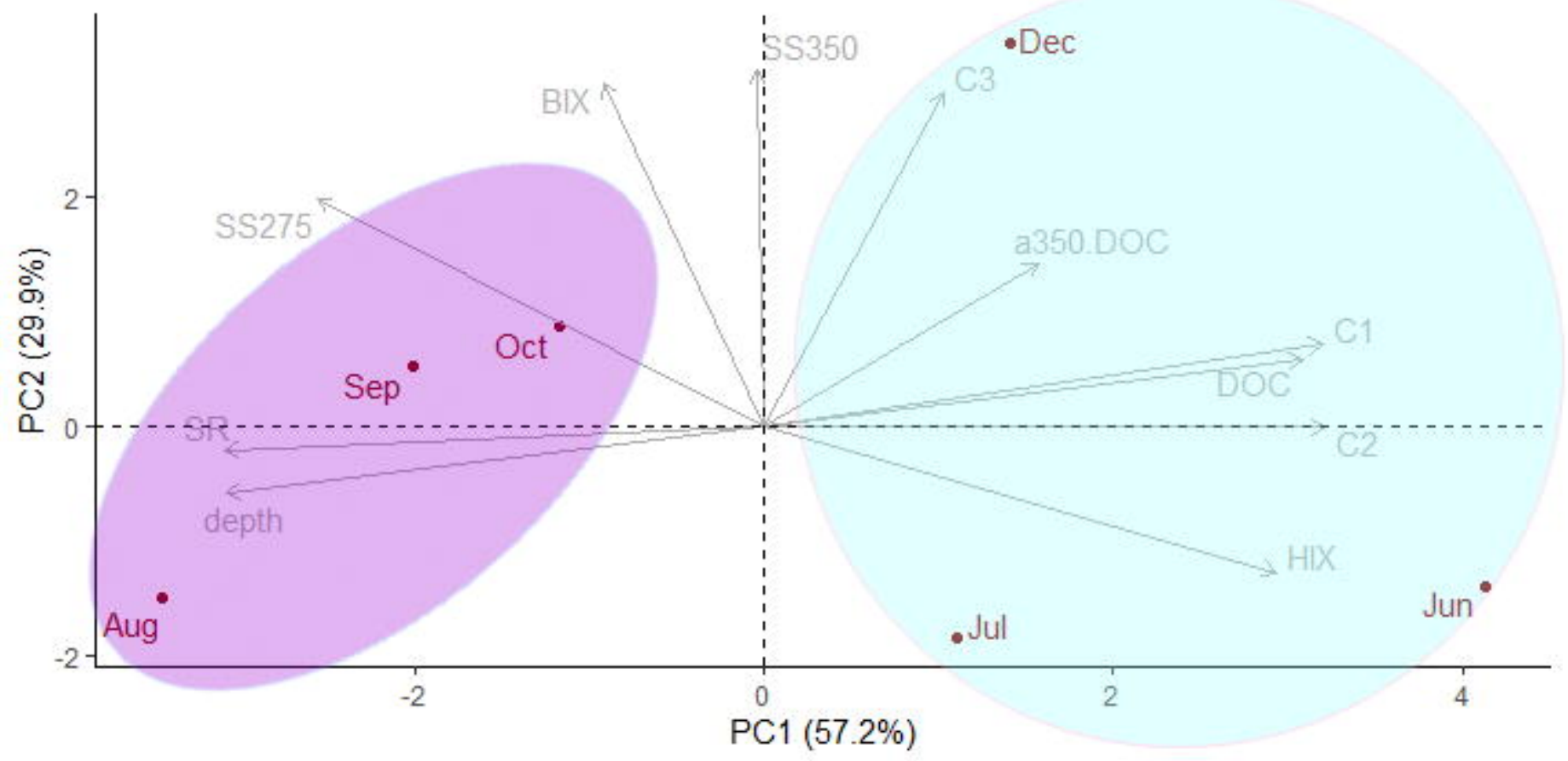



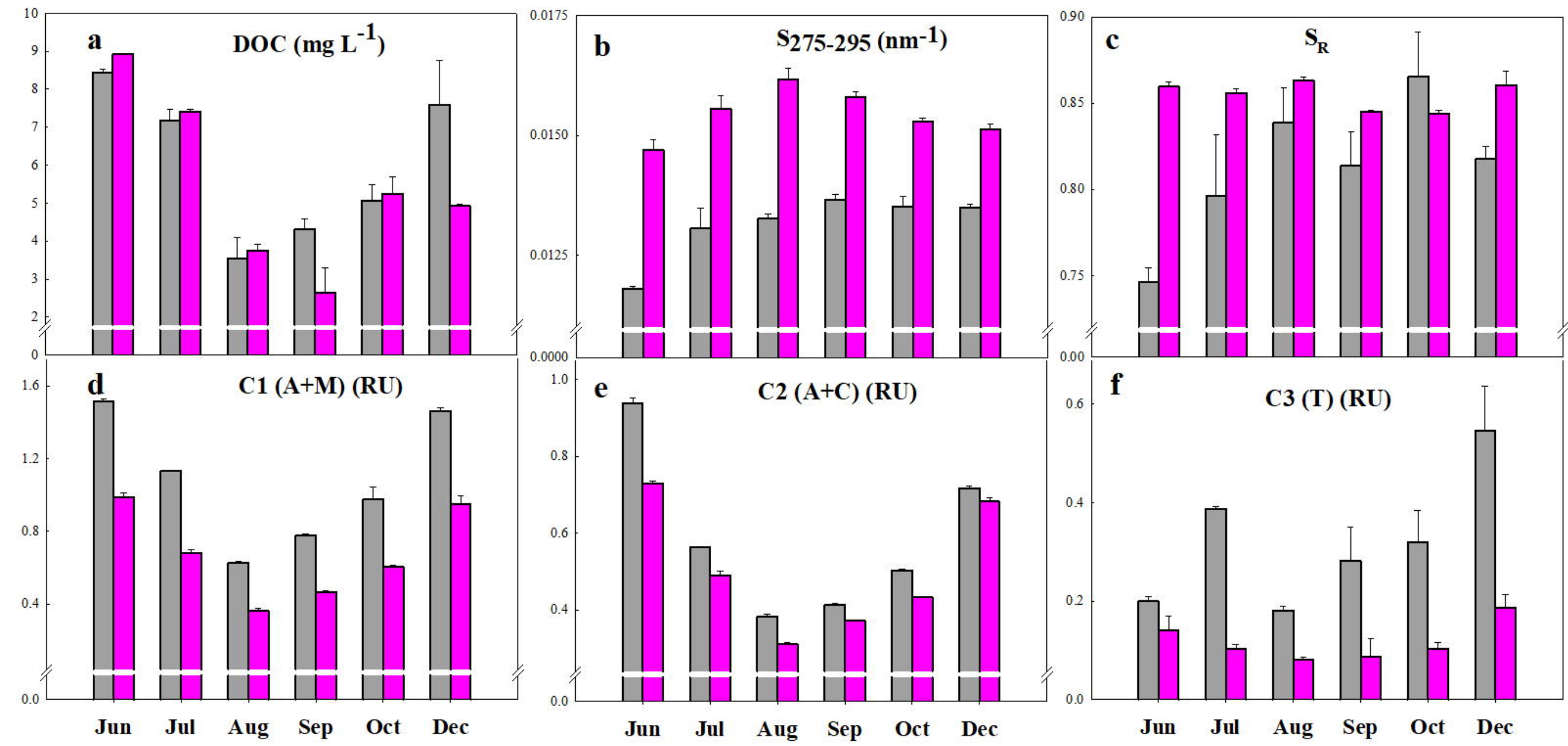

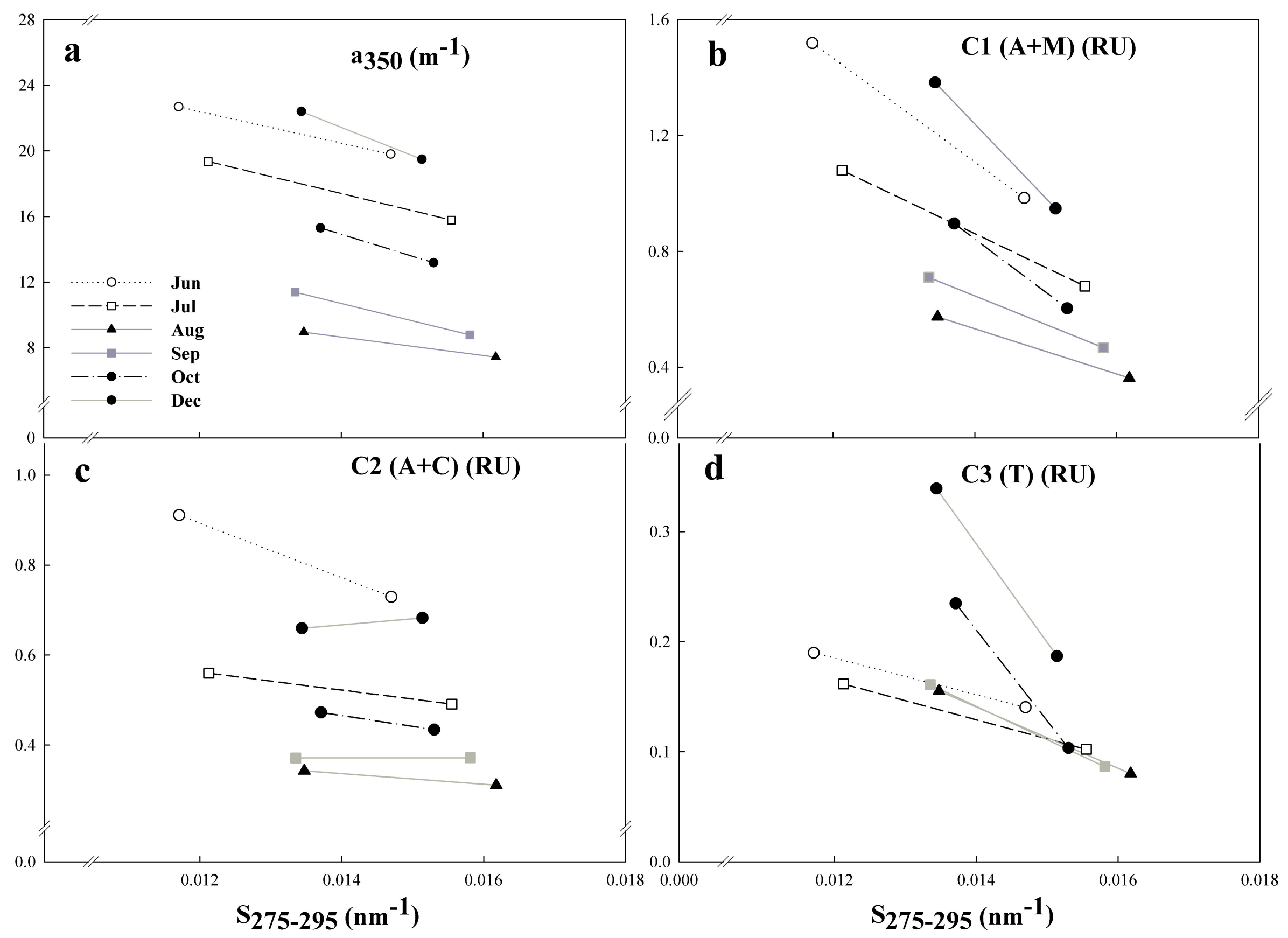